\title{
Los crímenes contra defensores de derechos humanos son crímenes de lesa humanidad
}

Por: Sebastián Latorre

Estudiante de Diseño Gráfico.

Sede Bogotá

Los casos en los que un defensor o defensora de derechos humanos, o un reclamante de tierras son asesinados, en adelante, deberán ser catalogados como crímenes de lesa humanidad.

Asesinatos, torturas, desapariciones, etc., ejecutadas contra un número de personas, por atreverse a reivindicar los derechos humanos o la recuperación de sus tierras.

Los delitos de lesa humanidad contienen un elemento material (ataque masivo o sistemático contra una población civil) y otro de orden subjetivo (el autor debe tener conocimiento de la existencia del ataque).

Al ser catalogados los crímenes contra defensores de derechos humanos como crímenes de lesa humanidad, nos abre puertas importantes para iniciar acciones legales que permitan disminuir los índices de impunidad reinantes en las investigaciones en Colombia, recursos y acciones que justamente por el pasar del tiempo ya no era procedente interponer, pero que atendiendo a la imprescriptibilidad que cobija este tipo de delitos, tendrán que surtir trámites ante los diferentes despachos judiciales; igualmente esta calificación abre camino para que casos resientes puedan ser investigados por la Corte Penal Internacional. 
"No callaré porque me sobra coraje y alzo mi voz"
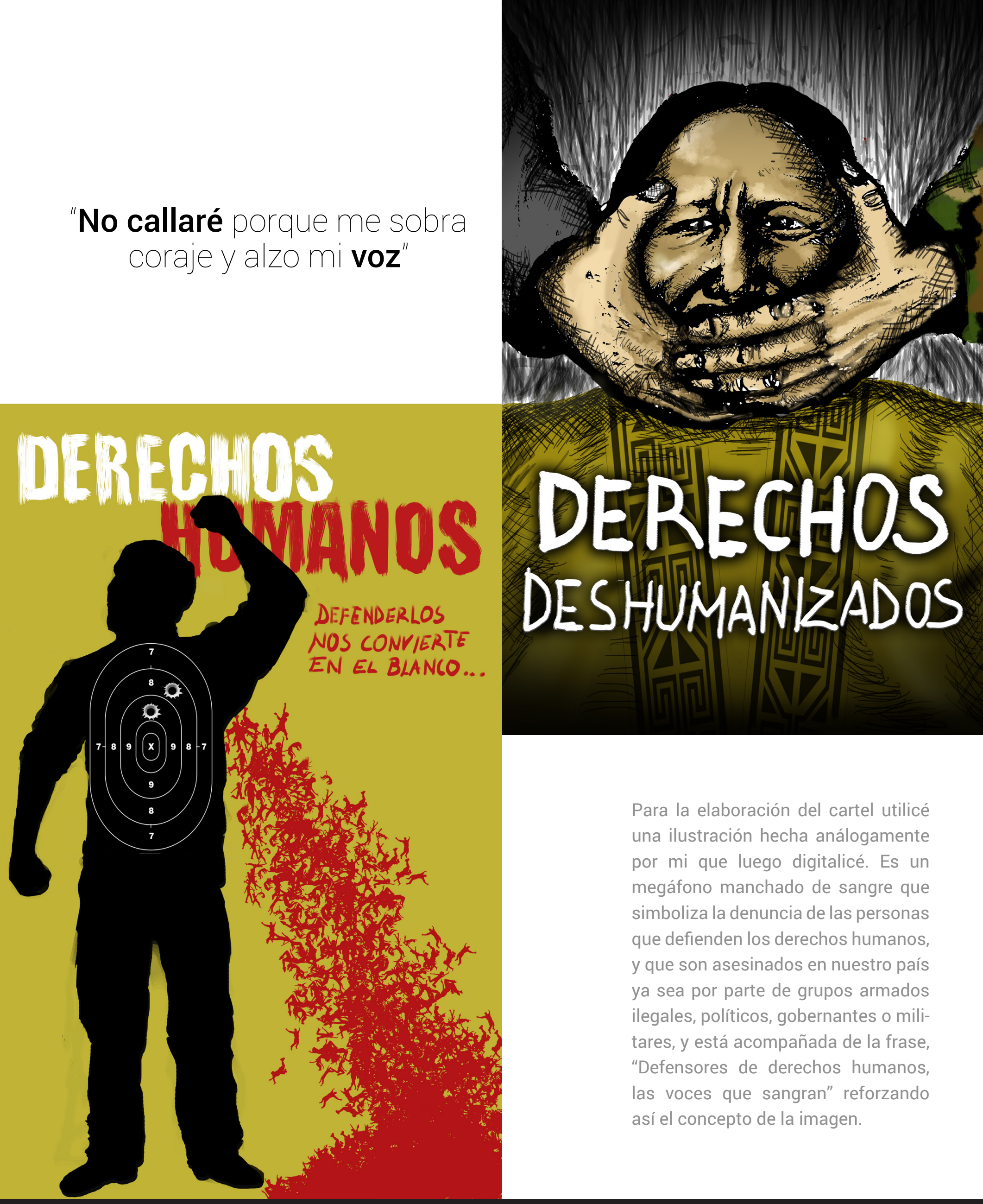

Para la elaboración del cartel utilicé una ilustración hecha análogamente por mi que luego digitalicé. Es un megáfono manchado de sangre que simboliza la denuncia de las personas que defienden los derechos humanos, y que son asesinados en nuestro país ya sea por parte de grupos armados ilegales, políticos, gobernantes o militares, y está acompañada de la frase, "Defensores de derechos humanos, las voces que sangran" reforzando así el concepto de la imagen. 


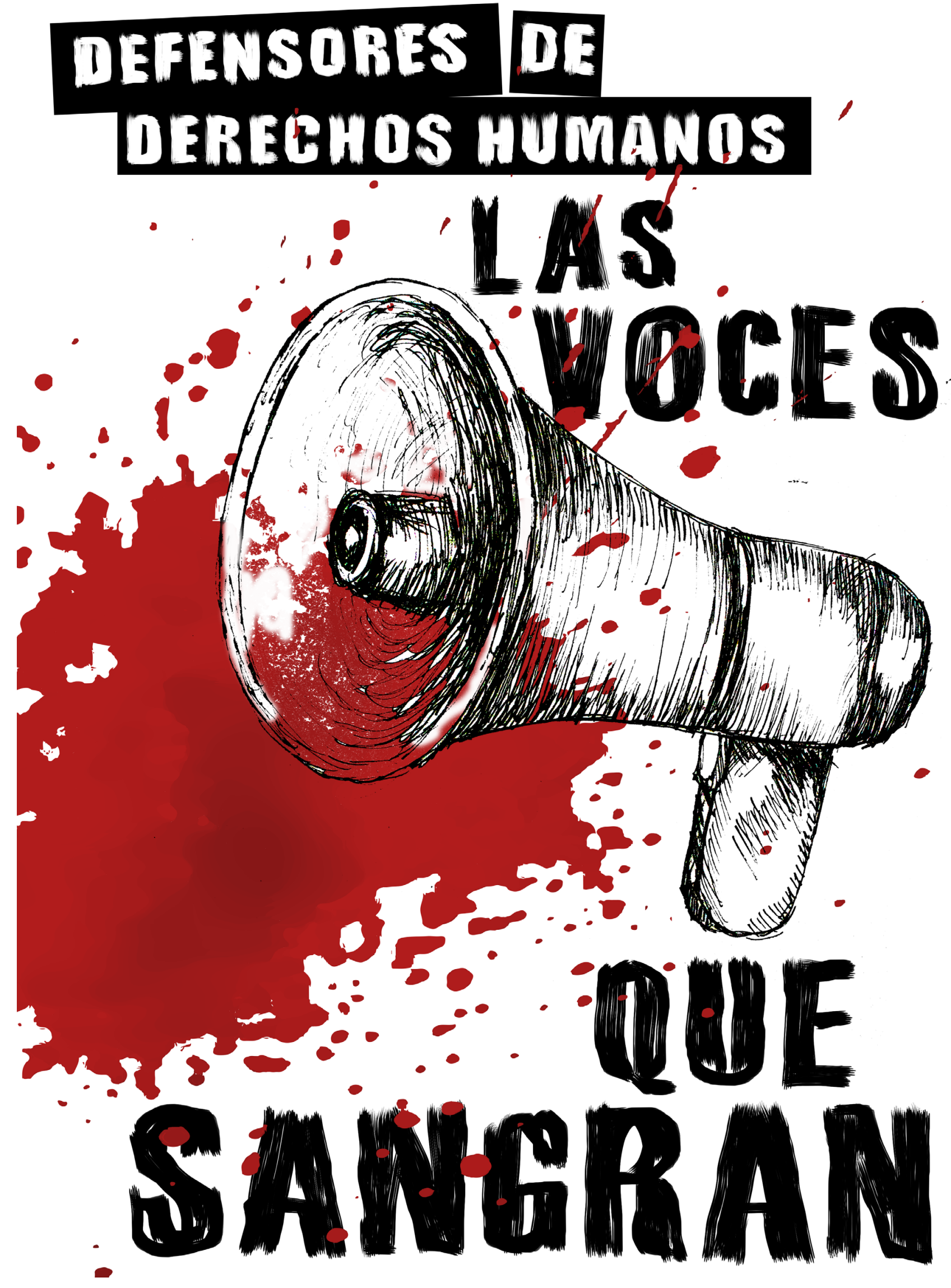

